\title{
Effect of Wild Strains of Lactococcus lactis on the Volatile Profile and the Sensory Characteristics of Ewes' Raw Milk Cheese
}

\author{
J. A. Centeno, F. J. Tomillo, E. Fernández-García, P. Gaya, and M. Nuñez \\ Instituto Nacional de Investigación y Tecnología Agraria y Alimentaria, \\ Madrid, 28040 Spain
}

\begin{abstract}
The production of volatile compounds by wild strains of Lactococcus lactis used as starter cultures and their effect on the sensory characteristics of ewes' raw milk cheese were investigated. Sixteen vats of cheese were manufactured and ripened for $120 \mathrm{~d}$ in two experiments, each of them duplicated. In the first experiment, milk was inoculated with different ratios of four wild Lactococcus lactis strains, two producing and two not producing branched-chain volatile compounds, and in the second experiment with different ratios of a commercial starter culture and the two strains producing branched-chain volatile compounds. Cheese $\mathrm{pH}$, proteolysis, and aminopeptidase activity increased when the strains producing branched-chain volatile compounds were inoculated at a higher rate. Fifty volatile compounds were identified in cheeses using a purge and trap system coupled to a gas chromatography-mass spectrometry apparatus. The relative abundances of 30 volatile compounds ( 8 alcohols, 5 aldehydes, 3 ketones, 12 esters, 1 sulfur compound, and 1 benzenic compound) were influenced by starter culture composition. 2-Methylpropanol, 3-methylbutanol, isobutyl acetate, isoamyl acetate, ethyl butyrate, isobutyl butyrate, and isoamyl butyrate were always more abundant in the cheeses made with a higher level of $L$. lactis strains producing branched-chain volatile compounds. Flavor intensity was enhanced by a high level of $L$. lactis strains producing branched-chain volatile compounds in the first experiment, in which four wild L. lactis strains were used as starter culture, but not in the second experiment, in which a combination of two wild L. lactis strains and the commercial starter culture were used. Flavor quality, as judged by trained panelists, was impaired in both experiments by a high level of L. lactis strains producing branched-chain volatile compounds.
\end{abstract}

(Key words: Lactococcus lactis, wild strain, volatile compound, raw milk cheese)

Received December 11, 2001.

Accepted May 19, 2002.

Corresponding author: M. Nuñez; e-mail: nunez@inia.es.
Abbreviation key: $\mathbf{B C V}$ = branched-chain volatile compounds, $\mathbf{C S C}=$ commercial starter culture.

\section{INTRODUCTION}

The request for a regularity in industrial cheese manufacture and a consistency in cheese quality has led to a reduced diversity in the characteristics of starter cultures used by the dairy industry. The fact that relatively few producers dominate the world market of starter cultures has considerably narrowed the availability of differentiated strains, particularly for aspects such as proteolysis and flavor production (Salama et al., 1993). Currently, in addition to consistency and quality, there is a growing consumer demand for a larger diversity in the flavor of cheeses and other fermented foods. The manufacture of new products requires the use of new strains with different, unusual characteristics. A need for strains of lactic acid bacteria with novel properties for use in the dairy industry has currently arisen.

The use of wild strains, that is, strains of lactic acid bacteria present in environments not yet affected by industrial strains, as starters for the development of new cheeses and/or flavors looks very promising (Ayad et al., 1999). Strains with the ability to produce unusual aroma compounds different from those produced by commercial starter cultures (CSC) may be found among the microbiota present in spontaneously fermented dairy products (Weerkamp et al., 1996; Cogan et al., 1997). In fact, certain flavor characteristics are observed in artisanal dairy products that normally are not or are poorly detected in industrial cheeses.

The enzymatic conversion of amino acids to aroma compounds plays a major role in cheese flavor development. Wild strains probably harbor more amino acid convertases than commercial strains, which could explain their ability to produce interesting flavors in cheese. Degradation products from aromatic amino acids, branched-chain amino acids, and methionine have been identified in a number of cheese varieties and contribute greatly to their typical flavor (Urbach, 1995; Molimard and Spinnler, 1996; Engels et al., 1997; Fox and Wallace, 1997; McSweeney and Sousa, 2000). 
Therefore, the flavor development in cheeses might be diversified or directed by controlling amino acid degradation (Rijnen et al., 1999; Ayad et al., 2001).

The Lactococcus lactis strains that produce branchedchain volatile compounds (BCV), usually called "malty" flavor compounds, derived from the catabolism of branched-chain amino acids in milk, are common in nature and are usually regarded as undesirable in the dairy industry (Morgan, 1970; Urbach, 1993). In early investigations (Jackson and Morgan, 1954), 3-methylbutanal was considered as the major contributor to malty flavors in milk. Since then, this and other aldehydes and alcohols derived from branched-chain amino acids have been identified in ripened cheeses (Bosset and Gauch, 1993; Engels et al., 1997), and they may contribute to cheese flavor in a positive way (Barbieri et al., 1994; Engels et al., 1997).

The aim of the present work is to determine the effect of wild $L$. lactis strains producing branched-chain volatile compounds $\left(\mathrm{BCV}^{+}\right.$strains), either alone or in combination with other strains of lactococci, on the volatile profile of ewes' raw milk cheese, and also to elucidate the influence of BCV on cheese sensory characteristics.

\section{MATERIALS AND METHODS}

\section{Lactic Cultures}

Four wild L. lactis strains (B6, B7, M21, and R20), isolated at our laboratory from ewes' raw milk cheese (Gaya et al., 1999), were used in experiments. Their proteolytic activity (Morales et al., 2001), the volatile compounds formed in milk (Morales, 2002, personal communication), and strain compatibility (Centeno et al., 2002) have been investigated. The L. lactis B7 and R20 strains produced large amounts of 2-methyl propanol, 3-methyl butanol and 3-methyl butanal, whereas L. lactis B6 and M21 strains did not. Wild strains producing, or not producing, branched-chain volatile compounds were used in pairs to minimize the risk of starter failure affecting strains of particular flavor characteristics.

Lactic cultures used in cheese-making trials were: (1) a $\mathrm{BCV}^{+}$culture consisting of equal parts of coagulated milk cultures of $L$. lactis ssp. lactis B7 and $L$. lactis ssp. cremoris $\mathrm{R} 20$; (2) a $\mathrm{BCV}^{-}$culture consisting of equal parts of coagulated milk cultures of $L$. lactis ssp. lactis B6 and L. lactis ssp. cremoris M21; and (3) a CSC, freeze-dried concentrated MA 016 (Rhodia Iberia, Madrid, Spain), which included three L. lactis ssp. lactis strains and one L. lactis ssp. cremoris strain, according to the manufacturer.

The wild lactococcal strains were maintained at $-80^{\circ} \mathrm{C}$ in MRS broth (Biolife, Milano, Italy) and subcultured twice in reconstituted skim milk before use in cheese manufacture. The CSC was added directly to the cheese milk.

\section{Cheese Manufacture and Sampling}

Cheese was manufactured from ewes' raw milk of good microbiological quality ( 1 to $4 \times 10^{5} \mathrm{cfu} / \mathrm{mL}$ total plate counts) in two different duplicated experiments carried out for four consecutive weeks. On each day of manufacture, four 33-L cheese vats were made, giving a total of 16 vats. In the first experiment, milk was inoculated with $\mathrm{BCV}^{-}$and $\mathrm{BCV}^{+}$cultures as follows: 10 $\mathrm{ml} / \mathrm{L}$ of $\mathrm{BCV}^{-}$for vat $1,6.7 \mathrm{ml} / \mathrm{L}$ of $\mathrm{BCV}^{-}$plus $3.3 \mathrm{ml} / \mathrm{L}$ $\mathrm{BCV}^{+}$for vat $2,3.3 \mathrm{ml} / \mathrm{L}$ of $\mathrm{BCV}^{-}$plus $6.7 \mathrm{ml} / \mathrm{L}$ of $\mathrm{BCV}^{+}$ for vat 3 , and $10 \mathrm{ml} / \mathrm{L}$ of $\mathrm{BCV}^{+}$for vat 4 . In the second experiment, $\mathrm{CSC}$ and $\mathrm{BCV}^{+}$culture were employed as follows: $0.008 \mathrm{U} / \mathrm{L}$ of CSC for vat 1, $0.006 \mathrm{U} / \mathrm{L}$ of CSC plus $2.5 \mathrm{ml} / \mathrm{L}$ of $\mathrm{BCV}^{+}$for vat 2, $0.004 \mathrm{U} / \mathrm{L}$ of CSC plus $5 \mathrm{ml} / \mathrm{L}$ of $\mathrm{BCV}^{+}$for vat 3 , and $0.002 \mathrm{U} / \mathrm{L}$ of CSC plus $7.5 \mathrm{ml} / \mathrm{L}$ of $\mathrm{BCV}^{+}$for vat 4 .

Rennet (0.15 ml/L of Maxiren, 1:15000 strength; Gist Brocades, Delft, The Netherlands) was added to milk 20 min after lactic cultures inoculation. The curds were cut 40 min after rennet addition into 6 to $8 \mathrm{~mm}$ cubes and scalded at $37^{\circ} \mathrm{C}$ for $15 \mathrm{~min}$. Whey was drained off and curds were distributed into cylindrical molds. Three cheeses, approximately $2 \mathrm{~kg}$ in weight, were obtained from each vat. Cheeses were pressed for $18 \mathrm{~h}$ at $20^{\circ} \mathrm{C}$, salted in brine $(150 \mathrm{~g} \mathrm{NaCl} / \mathrm{L})$ for $16 \mathrm{~h}$ at $12^{\circ} \mathrm{C}$, ripened at $12^{\circ} \mathrm{C}$, and analyzed after ripening for 60 and $120 \mathrm{~d}$.

\section{Microbiological Analyses and Cheese pH}

Cheese samples $(10 \mathrm{~g})$ were homogenized in $90 \mathrm{~mL}$ of $2 \%(\mathrm{wt} / \mathrm{vol})$ sodium citrate solution with a Stomacher 400 (Seward Laboratory, London, UK), and decimal dilutions were prepared in sterile $1 \mathrm{~g} / \mathrm{L}$ peptone solution. Total viable counts were determined on plate count agar (Difco Laboratories, Detroit, MI), incubated at $30^{\circ} \mathrm{C}$ for $3 \mathrm{~d}$. Lactic acid bacteria were determined on MRS agar (Biolife, Milano, Italy) acidified at $\mathrm{pH}$ 5.7, incubated at $30^{\circ} \mathrm{C}$ for $3 \mathrm{~d}$. All microbiological analyses were duplicated, and dilutions were spread on poured plates using a Spiral plater (Interscience, Saint-Nom-La-Bretèche, France).

Cheese $\mathrm{pH}$ measurement was duplicated after homogenizing $10 \mathrm{~g}$ of cheese with $20 \mathrm{ml}$ of distilled water at $70^{\circ} \mathrm{C}$ by means of a Stomacher 400 .

\section{Determination of Cheese Proteolysis and Aminopeptidase Activity}

Cheese proteolysis was determined in duplicate samples by the $o$-phthaldialdehyde method modified ac- 
cording to Garde et al. (1997), with only $50 \mu \mathrm{l}$ of filtered cheese extract in the assay mixture.

Aminopeptidase activity released into the cheese was measured in duplicate samples with lysine $p$-nitroanilide (Lys $p$-NA) and leucine $p$-nitroanilide (Leu $p$-NA) as substrates. The assay mixture contained $0.4 \mathrm{~mL}$ filtered cheese extract, $0.1 \mathrm{~mL}$ of a $25 \mathrm{~m} M$ solution of substrate in methanol, and $0.5 \mathrm{~mL}$ of $10 \mathrm{~m} M$-sodium phosphate buffer, pH 7.0 (Garde et al., 1997). One activity unit corresponded to the amount of enzyme producing 1 nmol $p$-nitroaniline/min per gram of cheese at $37^{\circ} \mathrm{C}$.

\section{Analysis of Volatile Compounds}

Cheese pieces wrapped in aluminum foil were vacuum packed and frozen at $-40^{\circ} \mathrm{C}$ until analysis. Before volatile extraction, frozen pieces were kept overnight at $4^{\circ} \mathrm{C}$ and then left to stabilize at room temperature for $90 \mathrm{~min}$. An automatic dynamic headspace apparatus (HP 7695 Purge and Trap; Hewlett-Packard, Palo Alto, CA) connected to a gas chromatograph-mass spectrometer (HP 6890; Hewlett-Packard) was used for the volatile compounds analysis. Duplicate 15-g cheese samples were homogenized in an analytical grinder (IKA; Labortechnik, Staufen, Germany), with $20 \mathrm{~g}$ of $\mathrm{Na}_{2} \mathrm{SO}_{4}$ and $75 \mu \mathrm{L}$ of an aqueous solution containing $0.5 \mathrm{mg} / \mathrm{mL}$ cyclohexanone and $0.5 \mathrm{mg} / \mathrm{mL}$ camphor as internal standards. An aliquot $(2 \mathrm{~g})$ of this mixture was subjected to helium purge in a 25-mL glass sparger (Schmidlin Co., Neuheim, Switzerland). Volatile compounds were concentrated in a Tenax Trap (Tekmar, Cincinnati, $\mathrm{OH})$, kept at $30^{\circ} \mathrm{C}$. Operating conditions were as follows: line temperature, $200^{\circ} \mathrm{C}$; helium flow, $40 \mathrm{ml} / \mathrm{min}$; sample temperature, $50^{\circ} \mathrm{C}$; equilibration time, $10 \mathrm{~min}$; purge time, $15 \mathrm{~min}$; dry purge time, $0.5 \mathrm{~min}$; desorption temperature, $230^{\circ} \mathrm{C}$; desorption time, $0.5 \mathrm{~min}$; split ratio 1:20; injection port temperature, $220^{\circ} \mathrm{C}$.

Chromatography was carried out with an HP-Innowax column $(60 \mathrm{~m}$ long $\times 0.25 \mathrm{~mm}$ i.d., $0.5 \mathrm{~mm}$ film thickness), with the following conditions: helium flow at injection, $1.4 \mathrm{~mL} / \mathrm{min}$ kept for $1.5 \mathrm{~min}$; helium flow at run, $1 \mathrm{~mL} / \mathrm{min}$; initial temperature, $45^{\circ} \mathrm{C}$ for $17 \mathrm{~min}$; $4^{\circ} \mathrm{C} / \mathrm{min}$ up to $110^{\circ} \mathrm{C}$ and kept for $10 \mathrm{~min} ; 15^{\circ} \mathrm{C} / \mathrm{min}$ up to $240^{\circ} \mathrm{C}$ and kept for $3 \mathrm{~min}$. Mass detection was performed in the scan mode, from 33 to $220 \mathrm{amu}$ at 2.23 $\mathrm{scan} / \mathrm{s}$ and ionization by EI at $70 \mathrm{eV}$. Data were collected with the HP ChemStation program, and volatile compounds were identified by comparison of spectra with the Wiley 275 Library and by comparison of their retention times with authentic standards (Oumer et al., 2001).

\section{Sensory Evaluation}

Representative slices of four cheeses per session were presented to 14 to 16 trained panelists in closed individ- ual Petri dishes. Flavor intensity, defined as the overall cheese flavor, of 60 - and 120-d-old cheeses was evaluated once on a 10-point intensity scale, which consisted of a 10-cm vertical line with upper (extremely strong) and lower (extremely mild) anchor points, as previously described (Nuñez et al., 1991). Flavor quality was evaluated once on a 10-point quality scale, with upper (like extremely) and lower (dislike extremely) anchor points. Panelists were also asked to report unusual flavor notes, belonging to families different from the "lactic" family (Bérodier et al., 1997).

\section{Statistical Analysis}

The ANOVA for each experiment with starter culture composition and cheese age as the main effects was performed using SPSS program Win version 9.0 (SPSS, Chicago, IL). Comparison of means was carried out using Tukey's test (Steel and Torrie, 1980). Pearson correlation coefficients were also calculated.

\section{RESULTS AND DISCUSSION}

\section{Microbial Groups, Cheese pH, and Proteolysis}

Total viable counts ranged from 8.1 to $8.8 \mathrm{log} \mathrm{cfu} / \mathrm{g}$ in 60 -d-old cheeses and from 7.9 to $8.2 \mathrm{log} \mathrm{cfu} / \mathrm{g}$ in 120 d-old cheeses, with no significant differences between cheeses corresponding to the same experiment and sampling time (Tables 1 and 2). Lactic acid bacteria reached counts in the range of 7.8 to $8.1 \mathrm{log} \mathrm{cfu} / \mathrm{g}$ in 60 and 120-d-old cheeses of both experiments. In cheeses made with $\mathrm{CSC}$ and $\mathrm{BCV}^{+}$wild strains (Table 2), but not in those made with $\mathrm{BCV}^{-}$and $\mathrm{BCV}^{+}$strains (Table 1), counts of lactic acid bacteria were higher when milk had been inoculated with a high level of $\mathrm{BCV}^{+}$strains. This fact was to be expected, since wild lactococcal strains die off slowly in cheese as compared with bacteria of starter cultures (Stadhouders, 1975; Ayad et al., 2000 ), possibly as a result of the stimulation provided by the production of $\mathrm{CO}_{2}$ from the decarboxylation of $\alpha$-ketoacids or the regeneration of NAD via the reduction of aldehydes to alcohols (Tucker and Morgan, 1967). A positive correlation $(\mathrm{r}=0.721)$ between $\mathrm{BCV}^{+}$ inoculation levels and counts of lactic acid bacteria in 60-d-old cheeses made with $\mathrm{CSC}$ and $\mathrm{BCV}^{+}$strains was found.

When $\mathrm{BCV}^{-}$and $\mathrm{BCV}^{+}$strains were used in combination, $\mathrm{pH}$ values were higher for cheeses made from milk inoculated with a high level of $\mathrm{BCV}^{+}$strains (Table 1), which also exhibited a more pronounced proteolysis. However, when cheeses were made using CSC and $\mathrm{BCV}^{+}$strains, no significant differences in $\mathrm{pH}$ values or proteolysis were recorded (Table 2). Ayad et al. (2000) did not find significant differences in proteolysis of 
Table 1. Microbial counts, $\mathrm{pH}$, proteolysis and aminopeptidase activity in cheeses ${ }^{1}$ made with wild strains of Lactococcus lactis not producing $\left(\mathrm{BCV}^{-}\right)$and producing $\left(\mathrm{BCV}^{+}\right)$branched-chain volatile compounds.

\begin{tabular}{|c|c|c|c|c|c|}
\hline & & $10 \mathrm{ml} / \mathrm{L} \mathrm{BCV}^{-}$ & $\begin{array}{l}6.7 \mathrm{ml} / \mathrm{L} \mathrm{BCV}^{-} \\
3.3 \mathrm{ml} / \mathrm{L} \mathrm{BCV}^{+}\end{array}$ & $\begin{array}{l}3.3 \mathrm{ml} / \mathrm{L} \mathrm{BCV}^{-} \\
6.7 \mathrm{ml} / \mathrm{L} \mathrm{BCV}^{+}\end{array}$ & $10 \mathrm{ml} / \mathrm{L} \mathrm{BCV}^{+}$ \\
\hline \multirow[t]{2}{*}{ Total viable counts } & $60 \mathrm{~d}$ & $8.16 \pm 0.20^{\mathrm{a}}$ & $8.61 \pm 0.25^{\mathrm{a}}$ & $8.44 \pm 0.12^{\mathrm{a}}$ & $8.53 \pm 0.21^{\mathrm{a}}$ \\
\hline & $120 \mathrm{~d}$ & $7.98 \pm 0.08^{\mathrm{a}}$ & $8.07 \pm 0.09^{\mathrm{a}}$ & $8.19 \pm 0.15^{\mathrm{a}}$ & $8.22 \pm 0.12^{\mathrm{a}}$ \\
\hline \multirow[t]{2}{*}{ Lactic acid bacteria } & $60 \mathrm{~d}$ & $7.80 \pm 0.12^{\mathrm{a}}$ & $7.94 \pm 0.11^{\mathrm{a}}$ & $8.12 \pm 0.05^{\mathrm{a}}$ & $7.98 \pm 0.26^{\mathrm{a}}$ \\
\hline & $120 \mathrm{~d}$ & $7.87 \pm 0.08^{\mathrm{a}}$ & $7.92 \pm 0.11^{\mathrm{a}}$ & $7.93 \pm 0.10^{\mathrm{a}}$ & $8.02 \pm 0.02^{\mathrm{a}}$ \\
\hline \multirow[t]{2}{*}{$\mathrm{pH}$} & $60 \mathrm{~d}$ & $5.07 \pm 0.01^{b}$ & $5.09 \pm 0.05^{\mathrm{b}}$ & $5.11 \pm 0.02^{\mathrm{ab}}$ & $5.17 \pm 0.01^{\mathrm{a}}$ \\
\hline & $120 \mathrm{~d}$ & $5.14 \pm 0.10^{\mathrm{a}}$ & $5.18 \pm 0.02^{\mathrm{a}}$ & $5.20 \pm 0.12^{\mathrm{a}}$ & $5.23 \pm 0.07^{\mathrm{a}}$ \\
\hline \multirow[t]{2}{*}{ Proteolysis } & $60 \mathrm{~d}$ & $0.45 \pm 0.01^{b}$ & $0.47 \pm 0.01^{\mathrm{b}}$ & $0.43 \pm 0.04^{b}$ & $0.54 \pm 0.03^{\mathrm{a}}$ \\
\hline & $120 \mathrm{~d}$ & $0.88 \pm 0.12^{\mathrm{a}}$ & $0.91 \pm 0.07^{\mathrm{a}}$ & $0.96 \pm 0.08^{\mathrm{a}}$ & $0.97 \pm 0.08^{\mathrm{a}}$ \\
\hline \multirow[t]{2}{*}{ Leu-aminopeptidase } & $60 \mathrm{~d}$ & $4.84 \pm 0.13^{b}$ & $4.98 \pm 0.26^{\mathrm{ab}}$ & $5.24 \pm 0.10^{\mathrm{ab}}$ & $6.35 \pm 1.32^{\mathrm{a}}$ \\
\hline & $120 \mathrm{~d}$ & $4.33 \pm 1.03^{\mathrm{a}}$ & $6.40 \pm 1.54^{\mathrm{a}}$ & $4.71 \pm 0.08^{\mathrm{a}}$ & $5.56 \pm 0.92^{\mathrm{a}}$ \\
\hline \multirow[t]{2}{*}{ Lys-aminopeptidase } & $60 \mathrm{~d}$ & $2.75 \pm 0.22^{\mathrm{b}}$ & $2.62 \pm 0.06^{b}$ & $3.06 \pm 0.46^{\mathrm{b}}$ & $3.73 \pm 0.13^{\mathrm{a}}$ \\
\hline & $120 \mathrm{~d}$ & $3.34 \pm 0.43^{\mathrm{a}}$ & $4.51 \pm 1.00^{\mathrm{a}}$ & $3.56 \pm 0.08^{\mathrm{a}}$ & $4.16 \pm 0.86^{\mathrm{a}}$ \\
\hline
\end{tabular}

${ }^{\mathrm{a}, \mathrm{b}}$ Means in a row with the same superscript do not differ significantly $(P>0.05)$.

${ }^{1}$ Mean $( \pm \mathrm{SD})$ of duplicate determinations on duplicate cheese-making trials.

Gouda-type cheeses made with different wild lactococcal strains as compared with control cheeses. In the present work, proteolysis after 60 and $120 \mathrm{~d}$ of ripening was significantly correlated with the respective $\mathrm{pH}$ values of cheeses made with $\mathrm{BCV}^{-}$and $\mathrm{BCV}^{+}$strains $(\mathrm{r}=$ 0.690 ), as well as with the respective $\mathrm{pH}$ values of cheeses made with $\mathrm{CSC}$ and $\mathrm{BCV}^{+}$strains $(\mathrm{r}=0.861)$.

Aminopeptidase activities on Leu $p$-NA and Lys $p$ $\mathrm{NA}$ in cheeses made with $\mathrm{BCV}^{-}$and $\mathrm{BCV}^{+}$strains (Table 1) and in cheeses made with $\mathrm{CSC}$ and $\mathrm{BCV}^{+}$strains (Table 2) were higher on day 60 when a high inoculum of $\mathrm{BCV}^{+}$strains had been added to milk. Values obtained for aminopeptidase activities were considerably higher than those reported for pasteurized milk cheeses using the same analytical method (Oumer et al., 2001).

\section{Volatile Compounds}

The 50 volatile compounds identified in ewes' raw milk cheeses in the present study included hydrocar- bons, aldehydes, alcohols, ketones, esters, sulfur compounds, and benzenic compounds. The relative abundances of 20 of these compounds were not influenced by starter culture composition in any of the two experiments, and their concentrations, with the exceptions of butanone and butanol, were generally low. This group of compounds (mean values for their relative abundances in 60-d-old cheeses in brackets) included propanal (0.17), propenal (2.92), butanal (0.04), nonanal (0.11), benzaldehyde (0.09), phenylacetaldehyde (0.02), butanol (8.71), 2-heptanol (0.70), hexanol (0.55), butanone (48.00), diacetyl (4.31), 2-pentanone (2.40), nonanone (0.16), propyl butyrate (1.90), ethyl decanoate (0.07), butyric acid (0.03), heptane (0.32), octane (0.79), 3 -methyl-1-heptene (0.10), and $\alpha$-pinene (0.15). Seven of these compounds (butanal, butanol, hexanol, 2-heptanol, 2-pentanone, butyric acid, and propyl butyrate) increased as cheese aged, one compound (benzaldehyde) decreased, and the rest were not influenced by cheese age (data not shown).

Table 2. Microbial counts, $\mathrm{pH}$, proteolysis and aminopeptidase activity in cheeses ${ }^{1}$ made with commercial starter culture (CSC) and wild strains of Lactococcus lactis producing branched-chain volatile compounds $\left(\mathrm{BCV}^{+}\right)$.

\begin{tabular}{llllll}
\hline & & & $0.006 \mathrm{U} / \mathrm{L} \mathrm{CSC}$ & $0.004 \mathrm{U} / \mathrm{L} \mathrm{CSC}$ & $0.002 \mathrm{U} / \mathrm{L} \mathrm{CSC}$ \\
& & $0.008 \mathrm{U} / \mathrm{L} \mathrm{CSC}$ & $2.5 \mathrm{ml} / \mathrm{BCV}^{+}$ & $5 \mathrm{ml} / \mathrm{LCV}^{+}$ & $7.5 \mathrm{ml} / \mathrm{L} \mathrm{BCV} \mathrm{CV}^{+}$ \\
\hline Total viable counts & $60 \mathrm{~d}$ & $8.67 \pm 0.13^{\mathrm{a}}$ & $8.58 \pm 0.11^{\mathrm{a}}$ & $8.72 \pm 0.11^{\mathrm{a}}$ & $8.76 \pm 0.03^{\mathrm{a}}$ \\
& $120 \mathrm{~d}$ & $8.02 \pm 0.02^{\mathrm{a}}$ & $8.00 \pm 0.01^{\mathrm{a}}$ & $7.93 \pm 0.04^{\mathrm{a}}$ & $7.95 \pm 0.07^{\mathrm{a}}$ \\
Lactic acid bacteria & $60 \mathrm{~d}$ & $7.92 \pm 0.01^{\mathrm{b}}$ & $7.98 \pm 0.05^{\mathrm{ab}}$ & $8.00 \pm 0.03^{\mathrm{ab}}$ & $8.10 \pm 0.11^{\mathrm{a}}$ \\
& $120 \mathrm{~d}$ & $7.85 \pm 0.06^{\mathrm{b}}$ & $7.82 \pm 0.03^{\mathrm{b}}$ & $7.93 \pm 0.04^{\mathrm{ab}}$ & $8.04 \pm 0.10^{\mathrm{a}}$ \\
$\mathrm{pH}$ & $60 \mathrm{~d}$ & $5.04 \pm 0.11^{\mathrm{a}}$ & $4.94 \pm 0.04^{\mathrm{a}}$ & $5.04 \pm 0.11^{\mathrm{a}}$ & $5.03 \pm 0.02^{\mathrm{a}}$ \\
& $120 \mathrm{~d}$ & $5.11 \pm 0.08^{\mathrm{a}}$ & $5.09 \pm 0.00^{\mathrm{a}}$ & $5.19 \pm 0.07^{\mathrm{a}}$ & $5.17 \pm 0.12^{\mathrm{a}}$ \\
Proteolysis & $60 \mathrm{~d}$ & $0.46 \pm 0.05^{\mathrm{a}}$ & $0.43 \pm 0.06^{\mathrm{a}}$ & $0.40 \pm 0.18^{\mathrm{a}}$ & $0.49 \pm 0.06^{\mathrm{a}}$ \\
& $120 \mathrm{~d}$ & $0.78 \pm 0.08^{\mathrm{a}}$ & $0.71 \pm 0.02^{\mathrm{a}}$ & $0.89 \pm 0.16^{\mathrm{a}}$ & $0.92 \pm 0.15^{\mathrm{a}}$ \\
Leu-aminopeptidase & $60 \mathrm{~d}$ & $7.52 \pm 1.44^{\mathrm{ab}}$ & $6.26 \pm 0.39^{\mathrm{b}}$ & $8.66 \pm 0.99^{\mathrm{a}}$ & $9.01 \pm 1.34^{\mathrm{a}}$ \\
& $120 \mathrm{~d}$ & $7.64 \pm 0.56^{\mathrm{a}}$ & $8.07 \pm 0.20^{\mathrm{a}}$ & $8.34 \pm 0.24^{\mathrm{a}}$ & $6.26 \pm 0.60^{\mathrm{b}}$ \\
Lys-aminopeptidase & $60 \mathrm{~d}$ & $4.34 \pm 0.43^{\mathrm{ab}}$ & $3.21 \pm 0.23^{\mathrm{b}}$ & $4.77 \pm 0.73^{\mathrm{a}}$ & $4.95 \pm 0.74^{\mathrm{a}}$ \\
& $120 \mathrm{~d}$ & $5.00 \pm 0.24^{\mathrm{a}}$ & $4.66 \pm 0.14^{\mathrm{a}}$ & $5.13 \pm 0.68^{\mathrm{a}}$ & $3.52 \pm 0.20^{\mathrm{b}}$ \\
\hline
\end{tabular}

${ }^{\mathrm{a}, \mathrm{b}}$ Means in a row with the same superscript do not differ significantly $(P>0.05)$.

${ }^{1}$ Mean $( \pm \mathrm{SD})$ of duplicate determinations on duplicate cheese-making trials. 
The relative abundances of 27 volatile compounds in cheeses made with $\mathrm{BCV}^{-}$and $\mathrm{BCV}^{+}$strains (Table 3) and of 14 volatile compounds in cheeses made with CSC and $\mathrm{BCV}^{+}$strains (Table 4) were influenced by starter culture composition. Alcohols, 2-methylpropanol and 3methylbutanol, and esters, isobutyl acetate, ethyl butyrate, isoamyl acetate, isobutyl butyrate and isoamyl butyrate, reached in both experiments and at both cheese ages significantly higher concentrations in cheeses made with the highest level of $\mathrm{BCV}^{+}$strains than in cheeses made without $\mathrm{BCV}^{+}$strains of L. lactis.

Methylaldehydes and methylalcohols are mostly derived from the branched-chain amino acids leucine, isoleucine and valine (Morgan et al., 1966; Sheldon et al., 1971; Ayad et al., 2000). The considerably higher amounts of 3-methylbutanal compared with those of 2methylbutanal found in our cheeses, as well as for the respective alcohols, may be attributed to a lesser activity of $\mathrm{BCV}^{+}$cultures in converting isoleucine to 2-methylbutanal than in converting leucine to 3-methylbutanal, as it was reported for Streptococcus lactis var. maltigenes strains (Tucker and Morgan, 1967).

Small amounts of 3-methylbutanal and 3-methylbutanol are normally found in cheese, and in some varieties these compounds can be present at high levels, even as major volatile constituents (Bosset and Gauch, 1993; Preininger et al., 1996; Engels et al., 1997). The highest abundance among all the volatile compounds determined in the present study was reached by 3 methylbutanol, in agreement with the levels of volatile compounds reported by Ayad et al. (2000) for 3-moold cheese manufactured with $L$. lactis wild strains as starter cultures. Although 3-methylbutanol was the dominant compound in fresh milk cultures of some wild lactococcal strains (Weerkamp et al., 1996), the aldehyde to alcohol conversion mostly takes place during cheese ripening (Sheldon et al., 1971; Dunn and Lindsay, 1985; Ayad et al., 2000).

High positive correlations were found between $\mathrm{BCV}^{+}$ inoculation level in milk and 2-methylpropanol $(\mathrm{r}=$ $0.955)$ or 3 -methylbutanol $(\mathrm{r}=0.935)$ in 60 -d-old cheeses. The relative abundances of methylalcohols were slightly lower after $120 \mathrm{~d}$ than after $60 \mathrm{~d}$ (Tables 3 and 4), a decrease that most likely will result from the reactions of these alcohols with fatty acids and other compounds present in the cheese.

Esters are formed in cheese by enzymatic or chemical reactions of short- to medium-chain fatty acids with alcohols (Barbieri et al., 1994; Molimard and Spinnler, 1996). Acetic acid and branched-chain fatty acids such as isobutyric acid may be derived from oxidative deamination of amino acids (Fox and Wallace, 1997), and some lactic acid bacteria also possess esterases (Morgan, 1976; Harper et al., 1980; Kamaly et al., 1988).
Lactococci and other lactic acid bacteria are able to produce ethanol from lactose (Cogan, 1995; Molimard and Spinnler, 1996), in addition to the alcohols produced from amino acid catabolism.

Ethyl, methyl, and isoamyl esters were found in skim milk cultures of $S$. lactis var. maltigenes by Sheldon et al. (1971), although these authors considered that esters were not produced by the organism but formed during the extraction of the culture distillate or concentration of the extract. More recently, the presence of esters such as ethyl acetate, ethyl butyrate, ethyl isovalerate, ethyl caproate, isoamyl acetate, or isoamyl isobutyrate in milk cultures of wild lactococcal strains has been reported (Weerkamp et al., 1996; Ayad et al., 1999). Most of these esters were found in the cheeses studied in the present work (Tables 3 and 4).

Relative abundances of the esters after $120 \mathrm{~d}$ were two to three times higher than after $60 \mathrm{~d}$, which seems to be in agreement with the decrease observed for ethanol and some methylalcohols during the same period. The relative abundance of esters such as isobutyl acetate $(\mathrm{r}=0.926)$, isoamyl acetate $(\mathrm{r}=0.952)$, isobutyl butyrate $(r=0.984)$, and isoamyl butyrate $(r=0.953)$ in 120 -d-old cheeses was correlated with $\mathrm{BCV}^{+}$inoculation level in milk.

\section{Sensory Characteristics}

Flavor intensity of cheeses made with different ratios of $\mathrm{BCV}^{-}$and $\mathrm{BCV}^{+}$wild strains of L. lactis was similar on $\mathrm{d} 60$, but after $120 \mathrm{~d}$ of ripening it was higher in cheeses made with high levels of $\mathrm{BCV}^{+}$strains (Table $5)$, and correlated significantly $(\mathrm{r}=0.738)$ with $\mathrm{BCV}^{+}$ inoculation level in milk. In cheeses made with CSC and $\mathrm{BCV}^{+}$strains, no significant differences in flavor intensity were found after 60 or $120 \mathrm{~d}$ (Table 6), and the correlation on d 120 with $\mathrm{BCV}^{+}$inoculation level in milk $(r=0.649)$ was nonsignificant. In cheeses made with $\mathrm{BCV}^{-}$and $\mathrm{BCV}^{+}$strains, flavor intensity was not correlated with proteolysis, but in cheeses made with $\mathrm{CSC}$ and $\mathrm{BCV}^{+}$strains a significant correlation $(\mathrm{r}=$ 0.777 ) was found on d 120.

Significant correlations between flavor intensity and volatile compounds such as 2-methyl-3-buten-1-ol ( $\mathrm{r}=$ $0.767)$, ethyl acetate $(r=0.808)$, ethyl butyrate $(r=$ $0.882)$, ethyl caproate $(r=0.799)$, and ethyl caprilate $(\mathrm{r}=0.882)$ were recorded on 120 for cheeses made with $\mathrm{BCV}^{-}$and $\mathrm{BCV}^{+}$strains. Correlations between volatile compounds and flavor intensity of 120-d-old cheeses made with $\mathrm{CSC}$ and $\mathrm{BCV}^{+}$strains were found for methyl caproate $(r=0.703)$, ethyl acetate $(r=0.782)$, ethyl caproate $(r=0.721)$, butyl acetate $(r=0.705)$, isobutyl acetate $(r=0.701)$, and isoamyl acetate $(r=0.716)$. The low perception thresholds of low carbon number esters 
Table 3. Relative abundances of volatile compounds ${ }^{1}$ significantly influenced by starter culture composition in cheeses made with $\mathrm{BCV}^{-}$and $\mathrm{BCV}^{+}$wild strains of Lactococcus lactis.

\begin{tabular}{|c|c|c|c|c|c|}
\hline & (d) & $10 \mathrm{ml} / \mathrm{L} \mathrm{BCV}^{-}$ & $\begin{array}{l}6.7 \mathrm{ml} / \mathrm{L} \mathrm{BCV}^{-} \\
3.3 \mathrm{ml} / \mathrm{L} \mathrm{BCV}^{+}\end{array}$ & $\begin{array}{l}3.3 \mathrm{ml} / \mathrm{L} \mathrm{BCV} \\
6.7 \mathrm{ml} / \mathrm{L} \mathrm{BCV}^{+}\end{array}$ & $10 \mathrm{ml} / \mathrm{L} \mathrm{BCV}^{+}$ \\
\hline \multicolumn{6}{|l|}{ Aldehydes } \\
\hline \multirow[t]{2}{*}{ Acetaldehyde } & 60 & $0.14 \pm 0.01^{\mathrm{b}}$ & $0.15 \pm 0.02^{\mathrm{b}}$ & $0.15 \pm 0.02^{\mathrm{ab}}$ & $0.18 \pm 0.02^{\mathrm{a}}$ \\
\hline & 120 & $0.13 \pm 0.03^{b}$ & $0.13 \pm 0.02^{\mathrm{b}}$ & $0.21 \pm 0.11^{b}$ & $0.22 \pm 0.11^{b}$ \\
\hline \multirow[t]{2}{*}{ Butanal } & 60 & $0.08 \pm 0.06^{\mathrm{a}}$ & $n d^{b}$ & $0.04 \pm 0.05^{\mathrm{ab}}$ & $0.09 \pm 0.01^{\mathrm{a}}$ \\
\hline & 120 & $0.09 \pm 0.07^{\mathrm{b}}$ & $0.08 \pm 0.05^{\mathrm{b}}$ & $0.14 \pm 0.09^{\mathrm{b}}$ & $0.13 \pm 0.06^{\mathrm{b}}$ \\
\hline \multirow[t]{2}{*}{ 2-Methylpropanal } & 60 & $0.03 \pm 0.00^{\mathrm{b}}$ & $0.04 \pm 0.01^{\mathrm{b}}$ & $0.04 \pm 0.00^{\mathrm{b}}$ & $0.04 \pm 0.00^{\mathrm{b}}$ \\
\hline & 120 & $0.01 \pm 0.01^{\mathrm{b}}$ & $0.03 \pm 0.01^{\mathrm{ab}}$ & $0.03 \pm 0.01^{\mathrm{a}}$ & $0.03 \pm 0.01^{\mathrm{a}}$ \\
\hline \multirow{2}{*}{ 2-Methylbutanal } & 60 & $0.07 \pm 0.05^{b}$ & $0.10 \pm 0.08^{\mathrm{b}}$ & $0.21 \pm 0.12^{\mathrm{b}}$ & $0.12 \pm 0.03^{\mathrm{ab}}$ \\
\hline & 120 & $0.09 \pm 0.06^{\mathrm{b}}$ & $0.20 \pm 0.07^{\mathrm{ab}}$ & $0.36 \pm 0.21^{\mathrm{a}}$ & $0.22 \pm 0.07^{\mathrm{ab}}$ \\
\hline \multirow{2}{*}{ 3-Methylbutanal } & 60 & $1.11 \pm 0.19^{\mathrm{b}}$ & $1.44 \pm 0.93^{\mathrm{b}}$ & $2.62 \pm 1.10^{\mathrm{b}}$ & $1.14 \pm 0.08^{\mathrm{b}}$ \\
\hline & 120 & $0.83 \pm 0.11^{b}$ & $1.44 \pm 0.42^{\mathrm{ab}}$ & $2.74 \pm 1.33^{\mathrm{a}}$ & $2.09 \pm 0.60^{\mathrm{ab}}$ \\
\hline \multicolumn{6}{|l|}{ Alcohols } \\
\hline \multirow{2}{*}{ Ethanol } & 60 & $61.58 \pm 6.72^{\mathrm{b}}$ & $94.94 \pm 42.52^{\mathrm{b}}$ & $138.04 \pm 41.75^{\mathrm{ab}}$ & $197.08 \pm 54.93^{\mathrm{a}}$ \\
\hline & 120 & $73.69 \pm 9.28^{\mathrm{b}}$ & $120.31 \pm 44.17^{b}$ & $116.68 \pm 63.29^{\mathrm{b}}$ & $156.39 \pm 83.53^{\mathrm{b}}$ \\
\hline \multirow[t]{2}{*}{ 2-Propen-1-ol } & 60 & $3.62 \pm 1.34^{\mathrm{b}}$ & $9.17 \pm 3.99^{\mathrm{a}}$ & $8.48 \pm 1.79^{\mathrm{ab}}$ & $12.05 \pm 1.51^{\mathrm{a}}$ \\
\hline & 120 & $3.63 \pm 2.11^{\mathrm{b}}$ & $4.31 \pm 0.53^{\mathrm{b}}$ & $5.25 \pm 1.11^{\mathrm{b}}$ & $6.63 \pm 1.83^{\mathrm{b}}$ \\
\hline \multirow[t]{2}{*}{ 2-Butanol } & 60 & $67.48 \pm 11.52^{\mathrm{b}}$ & $117.86 \pm 37.88^{\mathrm{ab}}$ & $129.37 \pm 49.30^{\mathrm{ab}}$ & $170.77 \pm 15.99^{a}$ \\
\hline & 120 & $118.20 \pm 36.28^{b}$ & $121.44 \pm 34.25^{\mathrm{b}}$ & $156.14 \pm 43.58^{b}$ & $169.72 \pm 11.95^{\mathrm{b}}$ \\
\hline \multirow{2}{*}{ 2-Methylpropanol } & 60 & $1.06 \pm 0.54^{\mathrm{c}}$ & $66.65 \pm 21.29^{b}$ & $113.08 \pm 6.01^{\mathrm{a}}$ & $155.71 \pm 36.47^{\mathrm{a}}$ \\
\hline & 120 & $1.46 \pm 0.11^{\mathrm{c}}$ & $61.84 \pm 7.07^{\mathrm{b}}$ & $112.28 \pm 14.31^{\mathrm{a}}$ & $150.89 \pm 37.51^{\mathrm{a}}$ \\
\hline \multirow[t]{2}{*}{ 3-Methylbutanol } & 60 & $4.64 \pm 0.90^{\mathrm{d}}$ & $229.01 \pm 33.50^{\mathrm{c}}$ & $350.18 \pm 47.35^{\mathrm{b}}$ & $454.48 \pm 78.14^{\mathrm{a}}$ \\
\hline & 120 & $4.60 \pm 1.24^{\mathrm{c}}$ & $205.54 \pm 20.75^{\mathrm{b}}$ & $334.73 \pm 65.74^{\mathrm{ab}}$ & $434.83 \pm 103.33^{a}$ \\
\hline \multirow[t]{2}{*}{ 2-Methyl-3-buten-1-ol } & 60 & $0.69 \pm 0.28^{\mathrm{b}}$ & $0.93 \pm 0.10^{\mathrm{b}}$ & $0.92 \pm 0.08^{\mathrm{b}}$ & $1.01 \pm 0.04^{\mathrm{b}}$ \\
\hline & 120 & $0.73 \pm 0.20^{\mathrm{b}}$ & $0.83 \pm 0.10^{\mathrm{ab}}$ & $1.03 \pm 0.16^{\mathrm{ab}}$ & $1.10 \pm 0.07^{\mathrm{a}}$ \\
\hline \multicolumn{6}{|l|}{ Ketones } \\
\hline \multirow[t]{2}{*}{ Acetone } & 60 & $2.71 \pm 0.56^{\mathrm{a}}$ & $2.40 \pm 0.12^{\mathrm{ab}}$ & $2.69 \pm 0.83^{\mathrm{a}}$ & $1.62 \pm 0.08^{b}$ \\
\hline & 120 & $2.70 \pm 0.75^{\mathrm{a}}$ & $2.82 \pm 0.82^{\mathrm{a}}$ & $2.99 \pm 1.50^{\mathrm{a}}$ & $2.29 \pm 0.58^{\mathrm{a}}$ \\
\hline \multirow[t]{2}{*}{ 2,3-Heptanodione } & 60 & $n d^{\mathrm{c}}$ & $1.91 \pm 1.22^{\mathrm{ab}}$ & $3.71 \pm 1.20^{\mathrm{a}}$ & $1.16 \pm 0.33^{\mathrm{bc}}$ \\
\hline & 120 & $\mathrm{nd}^{\mathrm{a}}$ & $0.99 \pm 0.43^{\mathrm{a}}$ & $1.30 \pm 0.99^{\mathrm{a}}$ & $0.98 \pm 0.74^{\mathrm{a}}$ \\
\hline 2-Heptanone & 60 & $2.05 \pm 0.36^{\mathrm{a}}$ & $1.09 \pm 1.06^{\mathrm{ab}}$ & $0.94 \pm 0.77^{\mathrm{ab}}$ & $0.27 \pm 0.04^{b}$ \\
\hline & 120 & $0.91 \pm 0.65^{\mathrm{a}}$ & $1.09 \pm 0.33^{\mathrm{a}}$ & $1.41 \pm 1.18^{\mathrm{a}}$ & $1.26 \pm 0.49^{\mathrm{a}}$ \\
\hline Esters & & & & & \\
\hline Propyl acetate & 60 & $0.38 \pm 0.45^{\mathrm{b}}$ & $0.45 \pm 0.56^{\mathrm{b}}$ & $1.02 \pm 1.19^{b}$ & $3.13 \pm 0.60^{\mathrm{a}}$ \\
\hline & 120 & $4.24 \pm 3.72^{\mathrm{a}}$ & $2.87 \pm 1.31^{\mathrm{a}}$ & $5.95 \pm 4.26^{\mathrm{a}}$ & $6.86 \pm 2.03^{\mathrm{a}}$ \\
\hline 2-Butyl acetate & 60 & $0.14 \pm 0.11^{\mathrm{b}}$ & $0.15 \pm 0.12^{\mathrm{b}}$ & $0.46 \pm 0.37^{\mathrm{ab}}$ & $0.77 \pm 0.18^{\mathrm{a}}$ \\
\hline & 120 & $0.32 \pm 0.12^{\mathrm{b}}$ & $0.40 \pm 0.11^{\mathrm{ab}}$ & $0.94 \pm 0.49^{\mathrm{a}}$ & $0.97 \pm 0.24^{\mathrm{a}}$ \\
\hline Isobutyl acetate & 60 & $\mathrm{nd}^{\mathrm{c}}$ & $0.12 \pm 0.14^{\mathrm{c}}$ & $0.50 \pm 0.21^{\mathrm{b}}$ & $0.89 \pm 0.04^{\mathrm{a}}$ \\
\hline & 120 & $n d^{d}$ & $0.27 \pm 0.05^{\mathrm{c}}$ & $0.85 \pm 0.23^{\mathrm{b}}$ & $1.31 \pm 0.07^{\mathrm{a}}$ \\
\hline Ethyl butyrate & 60 & $1.20 \pm 0.12^{\mathrm{b}}$ & $1.71 \pm 0.51^{\mathrm{ab}}$ & $2.16 \pm 0.64^{\mathrm{ab}}$ & $2.99 \pm 1.27^{\mathrm{a}}$ \\
\hline & 120 & $2.30 \pm 0.50^{\mathrm{b}}$ & $2.87 \pm 0.30^{\mathrm{b}}$ & $3.45 \pm 0.69^{\mathrm{ab}}$ & $4.74 \pm 1.35^{\mathrm{a}}$ \\
\hline Butyl acetate & 60 & $0.12 \pm 0.14^{\mathrm{ab}}$ & $0.06 \pm 0.07^{\mathrm{b}}$ & $0.09 \pm 0.11^{\mathrm{ab}}$ & $0.28 \pm 0.04^{\mathrm{a}}$ \\
\hline & 120 & $0.57 \pm 0.39^{\mathrm{a}}$ & $0.54 \pm 0.14^{\mathrm{a}}$ & $1.12 \pm 0.89^{\mathrm{a}}$ & $1.31 \pm 0.21^{\mathrm{a}}$ \\
\hline Isoamyl acetate & 60 & $\mathrm{nd}^{\mathrm{c}}$ & $3.44 \pm 0.97^{\mathrm{b}}$ & $6.71 \pm 3.88^{\mathrm{b}}$ & $17.72 \pm 10.20^{\mathrm{a}}$ \\
\hline & 120 & $\mathrm{nd}^{\mathrm{c}}$ & $5.98 \pm 0.40^{\mathrm{b}}$ & $14.78 \pm 7.15^{\mathrm{a}}$ & $24.73 \pm 8.65^{\mathrm{a}}$ \\
\hline Isobutyl butyrate & 60 & $\mathrm{nd}^{\mathrm{d}}$ & $0.30 \pm 0.03^{c}$ & $0.57 \pm 0.03^{b}$ & $0.80 \pm 0.20^{\mathrm{a}}$ \\
\hline & 120 & $n d^{d}$ & $0.55 \pm 0.10^{\mathrm{c}}$ & $1.12 \pm 0.13^{\mathrm{b}}$ & $1.64 \pm 0.44^{\mathrm{a}}$ \\
\hline Ethyl caproate & 60 & $1.58 \pm 0.28^{\mathrm{b}}$ & $2.76 \pm 0.86^{\mathrm{ab}}$ & $3.56 \pm 1.77^{\mathrm{ab}}$ & $5.83 \pm 3.08^{\mathrm{a}}$ \\
\hline & 120 & $3.19 \pm 0.30^{\mathrm{a}}$ & $4.26 \pm 1.19^{\mathrm{a}}$ & $6.43 \pm 3.38^{\mathrm{a}}$ & $9.48 \pm 4.90^{\mathrm{a}}$ \\
\hline Isoamyl butyrate & 60 & $\mathrm{nd}^{\mathrm{d}}$ & $0.52 \pm 0.07^{\mathrm{c}}$ & $0.92 \pm 0.06^{\mathrm{b}}$ & $1.46 \pm 0.18^{\mathrm{a}}$ \\
\hline & 120 & $n d^{d}$ & $1.00 \pm 0.16^{\mathrm{c}}$ & $2.01 \pm 0.15^{\mathrm{b}}$ & $3.06 \pm 0.39^{\mathrm{a}}$ \\
\hline Ethyl caprilate & 60 & $n d^{b}$ & $0.04 \pm 0.05^{\mathrm{ab}}$ & $0.09 \pm 0.10^{\mathrm{ab}}$ & $0.19 \pm 0.09^{\mathrm{a}}$ \\
\hline & 120 & $0.02 \pm 0.03^{b}$ & $0.10 \pm 0.03^{\mathrm{ab}}$ & $0.17 \pm 0.10^{\mathrm{ab}}$ & $0.27 \pm 0.17^{\mathrm{a}}$ \\
\hline Methyl caproate & 60 & $0.42 \pm 0.10^{\mathrm{b}}$ & $0.29 \pm 0.18^{\mathrm{ab}}$ & $0.32 \pm 0.09^{b}$ & $0.37 \pm 0.08^{\mathrm{b}}$ \\
\hline & 120 & $0.24 \pm 0.03^{c}$ & $0.28 \pm 0.02^{\mathrm{bc}}$ & $0.40 \pm 0.04^{\mathrm{a}}$ & $0.34 \pm 0.06^{\mathrm{ab}}$ \\
\hline Benzenic compounds & & & & & \\
\hline Toluene & 60 & $1.81 \pm 0.52^{\mathrm{a}}$ & $1.37 \pm 0.18^{\mathrm{a}}$ & $1.27 \pm 0.63^{\mathrm{a}}$ & $1.19 \pm 0.35^{\mathrm{a}}$ \\
\hline & 120 & $1.15 \pm 0.31^{b}$ & $1.09 \pm 0.40^{\mathrm{b}}$ & $1.81 \pm 0.11^{\mathrm{a}}$ & $1.40 \pm 0.10^{\mathrm{ab}}$ \\
\hline Sulfur compounds & & & & & \\
\hline Dimethylsulfude & 60 & $n d^{b}$ & $0.04 \pm 0.05^{\mathrm{ab}}$ & $0.07 \pm 0.05^{\mathrm{ab}}$ & $0.09 \pm 0.02^{\mathrm{a}}$ \\
\hline & 120 & $0.19 \pm 0.07^{\mathrm{a}}$ & $0.15 \pm 0.06^{\mathrm{a}}$ & $0.17 \pm 0.04^{\mathrm{a}}$ & $0.17 \pm 0.07^{\mathrm{a}}$ \\
\hline
\end{tabular}

a,b,c Means in a row with the same superscript do not differ significantly $(P>0.05)$.

${ }^{1}$ Mean $( \pm \mathrm{SD})$ of duplicate determinations on duplicate cheese-making trials; nd, not detected. 
Table 4. Relative abundances of volatile compounds ${ }^{1}$ significantly influenced by starter culture composition in cheeses made with commercial starter culture $(\mathrm{CSC})$ and $\mathrm{BCV}^{+}$wild strains of Lactococcus lactis.

\begin{tabular}{|c|c|c|c|c|c|}
\hline & (d) & $0.008 \mathrm{U} / \mathrm{L} \mathrm{CSC}$ & $\begin{array}{l}0.006 \mathrm{U} / \mathrm{L} \mathrm{CSC} \\
2.5 \mathrm{ml} / \mathrm{L} \mathrm{BCV}\end{array}$ & $\begin{array}{l}0.004 \mathrm{U} / \mathrm{L} \mathrm{CSC} \\
5 \mathrm{ml} / \mathrm{L} \mathrm{BCV}^{+}\end{array}$ & $\begin{array}{l}0.002 \mathrm{U} / \mathrm{L} \mathrm{CSC} \\
7.5 \mathrm{~mL} / \mathrm{L} \mathrm{BCV}^{+}\end{array}$ \\
\hline \multicolumn{6}{|l|}{ Aldehydes } \\
\hline \multirow[t]{2}{*}{ Methylbutanal } & 60 & $n d^{b}$ & $0.04 \pm 0.08^{b}$ & $0.10 \pm 0.07^{\mathrm{ab}}$ & $0.16 \pm 0.01^{\mathrm{a}}$ \\
\hline & 120 & $0.16 \pm 0.01^{\mathrm{b}}$ & $0.22 \pm 0.04^{\mathrm{ab}}$ & $0.21 \pm 0.03^{\mathrm{ab}}$ & $0.27 \pm 0.05^{\mathrm{a}}$ \\
\hline \multirow[t]{2}{*}{ 3-Methylbutanal } & 60 & $0.88 \pm 0.09^{b}$ & $1.27 \pm 0.17^{\mathrm{ab}}$ & $1.86 \pm 0.46^{\mathrm{a}}$ & $1.88 \pm 0.33^{\mathrm{a}}$ \\
\hline & 120 & $1.28 \pm 0.23^{b}$ & $1.88 \pm 0.17^{\mathrm{a}}$ & $1.82 \pm 0.29^{\mathrm{a}}$ & $2.17 \pm 0.14^{\mathrm{a}}$ \\
\hline \multicolumn{6}{|l|}{ Alcohols } \\
\hline \multirow{2}{*}{ 1-Propanol } & 60 & $105.95 \pm 44.71^{a}$ & $49.75 \pm 24.41^{\mathrm{a}}$ & $70.03 \pm 23.40^{\mathrm{a}}$ & $90.49 \pm 4.72^{\mathrm{a}}$ \\
\hline & 120 & $105.23 \pm 34.15^{\mathrm{ab}}$ & $76.36 \pm 20.18^{\mathrm{ab}}$ & $140.45 \pm 24.80^{\mathrm{a}}$ & $56.82 \pm 50.28^{\mathrm{b}}$ \\
\hline \multirow[t]{2}{*}{ 2-Methylpropanol } & 60 & $0.99 \pm 0.17^{\mathrm{d}}$ & $74.56 \pm 6.70^{\mathrm{c}}$ & $126.20 \pm 7.17^{\mathrm{b}}$ & $169.06 \pm 12.52^{\mathrm{a}}$ \\
\hline & 120 & $0.79 \pm 0.50^{\mathrm{d}}$ & $68.50 \pm 6.13^{\mathrm{c}}$ & $115.08 \pm 5.57^{\mathrm{b}}$ & $160.66 \pm 13.70^{\mathrm{a}}$ \\
\hline \multirow[t]{2}{*}{ 2-Pentanol } & 60 & $5.96 \pm 1.69^{\mathrm{a}}$ & $7.32 \pm 3.00^{\mathrm{a}}$ & $6.47 \pm 2.40^{\mathrm{a}}$ & $8.30 \pm 4.82^{\mathrm{a}}$ \\
\hline & 120 & $16.34 \pm 3.19^{b}$ & $27.44 \pm 7.31^{\mathrm{a}}$ & $26.53 \pm 2.03^{\mathrm{a}}$ & $29.13 \pm 2.38^{\mathrm{a}}$ \\
\hline \multirow[t]{2}{*}{ 3-Methylbutanol } & 60 & $2.38 \pm 0.47^{\mathrm{d}}$ & $289.83 \pm 14.78^{\mathrm{c}}$ & $410.70 \pm 18.94^{\mathrm{b}}$ & $495.61 \pm 25.57^{\mathrm{a}}$ \\
\hline & 120 & $2.54 \pm 0.31^{\mathrm{d}}$ & $263.63 \pm 14.67^{\mathrm{c}}$ & $362.76 \pm 4.46^{\mathrm{b}}$ & $464.87 \pm 31.07^{\mathrm{a}}$ \\
\hline \multirow[t]{2}{*}{ 2-Methyl-3-buten-1-ol } & 60 & $1.24 \pm 0.03^{b}$ & $1.49 \pm 0.11^{\mathrm{a}}$ & $1.40 \pm 0.03^{\mathrm{ab}}$ & $1.39 \pm 0.11^{\mathrm{ab}}$ \\
\hline & 120 & $1.38 \pm 0.07^{\mathrm{b}}$ & $1.43 \pm 0.10^{\mathrm{ab}}$ & $1.51 \pm 0.12^{\mathrm{ab}}$ & $1.63 \pm 0.13^{\mathrm{a}}$ \\
\hline \multicolumn{6}{|l|}{ Esters } \\
\hline \multirow{2}{*}{ Ethyl acetate } & 60 & $1.22 \pm 0.30^{\mathrm{a}}$ & $1.27 \pm 0.20^{\mathrm{a}}$ & $1.39 \pm 0.25^{\mathrm{a}}$ & $1.56 \pm 0.15^{\mathrm{a}}$ \\
\hline & 120 & $1.63 \pm 0.26^{\mathrm{b}}$ & $1.59 \pm 0.34^{\mathrm{b}}$ & $2.29 \pm 0.57^{\mathrm{ab}}$ & $2.88 \pm 0.77^{\mathrm{a}}$ \\
\hline \multirow[t]{2}{*}{ Isobutyl acetate } & 60 & $n d^{c}$ & $0.04 \pm 0.08^{c}$ & $0.30 \pm 0.07^{\mathrm{b}}$ & $0.49 \pm 0.04^{\mathrm{a}}$ \\
\hline & 120 & $n d^{\mathrm{c}}$ & $0.34 \pm 0.09^{\mathrm{c}}$ & $0.84 \pm 0.27^{\mathrm{b}}$ & $1.34 \pm 0.28^{\mathrm{a}}$ \\
\hline \multirow[t]{2}{*}{ Ethyl butyrate } & 60 & $1.50 \pm 0.10^{\mathrm{b}}$ & $1.44 \pm 0.12^{\mathrm{b}}$ & $1.42 \pm 0.16^{\mathrm{b}}$ & $1.76 \pm 0.07^{\mathrm{a}}$ \\
\hline & 120 & $2.86 \pm 0.18^{\mathrm{b}}$ & $2.90 \pm 0.21^{b}$ & $3.46 \pm 0.26^{\mathrm{ab}}$ & $4.11 \pm 0.88^{\mathrm{a}}$ \\
\hline \multirow[t]{2}{*}{ Isoamyl acetate } & 60 & $n \mathrm{~d}^{\mathrm{c}}$ & $3.41 \pm 0.44^{\mathrm{b}}$ & $6.23 \pm 3.98^{\mathrm{b}}$ & $9.15 \pm 1.44^{\mathrm{a}}$ \\
\hline & 120 & $n d^{c}$ & $6.11 \pm 0.83^{b}$ & $17.07 \pm 7.73^{\mathrm{a}}$ & $24.44 \pm 11.24^{\mathrm{a}}$ \\
\hline \multirow[t]{2}{*}{ Isobutyl butyrate } & 60 & nd & $0.26 \pm 0.01^{\mathrm{c}}$ & $0.43 \pm 0.03^{\mathrm{b}}$ & $0.68 \pm 0.06^{\mathrm{a}}$ \\
\hline & 120 & $n d^{d}$ & $0.57 \pm 0.03^{c}$ & $1.10 \pm 0.07^{\mathrm{b}}$ & $1.62 \pm 0.11^{\mathrm{a}}$ \\
\hline \multirow[t]{2}{*}{ Ethyl caproate } & 60 & $2.12 \pm 0.33^{\mathrm{ab}}$ & $1.94 \pm 0.13^{\mathrm{b}}$ & $2.13 \pm 0.11^{\mathrm{ab}}$ & $2.47 \pm 0.11^{\mathrm{a}}$ \\
\hline & 120 & $4.33 \pm 0.35^{\mathrm{b}}$ & $3.89 \pm 0.07^{b}$ & $5.48 \pm 0.87^{\mathrm{ab}}$ & $6.34 \pm 1.44^{\mathrm{a}}$ \\
\hline \multirow[t]{2}{*}{ Isoamyl butyrate } & 60 & $\mathrm{nd}^{\mathrm{d}}$ & $0.50 \pm 0.06^{\mathrm{c}}$ & $0.78 \pm 0.10^{\mathrm{b}}$ & $1.12 \pm 0.10^{\mathrm{a}}$ \\
\hline & 120 & $n d^{c}$ & $1.15 \pm 0.22^{b}$ & $2.11 \pm 0.44^{\mathrm{ab}}$ & $3.00 \pm 0.77^{\mathrm{a}}$ \\
\hline
\end{tabular}

a,b,c,d Means in a row with the same superscript do not differ significantly $(P>0.05)$.

${ }^{1}$ Mean $( \pm \mathrm{SD})$ of duplicate determinations on duplicate cheese-making trials; nd, not detected.

Table 5. Flavor intensity and flavor quality scores ${ }^{1}$ of cheeses made with $\mathrm{BCV}^{-}$and $\mathrm{BCV}^{+}$wild strains of Lactococcus lactis.

\begin{tabular}{llllll}
\hline & & & $6.7 \mathrm{ml} / \mathrm{L} \mathrm{BCV}^{-}$ & $3.3 \mathrm{ml} / \mathrm{L} \mathrm{BCV}^{-}$ & \\
& $(\mathrm{d})$ & $10 \mathrm{ml} / \mathrm{L} \mathrm{BCV}^{-}$ & $3.3 \mathrm{ml} / \mathrm{L} \mathrm{BCV}^{+}$ & $6.7 \mathrm{ml} / \mathrm{L} \mathrm{BCV}^{+}$ & $10 \mathrm{ml} / \mathrm{L} \mathrm{BCV}^{+}$ \\
\hline Flavor intensity & 60 & $6.91 \pm 0.32^{\mathrm{a}}$ & $6.93 \pm 0.33^{\mathrm{a}}$ & $6.82 \pm 0.16^{\mathrm{a}}$ & $7.22 \pm 0.35^{\mathrm{a}}$ \\
& 120 & $7.14 \pm 0.17^{\mathrm{b}}$ & $7.51 \pm 0.08^{\mathrm{ab}}$ & $7.69 \pm 0.06^{\mathrm{a}}$ & $7.82 \pm 0.46^{\mathrm{a}}$ \\
Flavor quality & 60 & $6.78 \pm 0.51^{\mathrm{a}}$ & $6.25 \pm 1.11^{\mathrm{a}}$ & $6.32 \pm 1.22^{\mathrm{a}}$ & $6.40 \pm 0.45^{\mathrm{a}}$ \\
& 120 & $6.73 \pm 0.37^{\mathrm{b}}$ & $6.27 \pm 0.69^{\mathrm{ab}}$ & $6.26 \pm 0.30^{\mathrm{ab}}$ & $5.41 \pm 0.39^{\mathrm{a}}$ \\
\hline
\end{tabular}

${ }^{\mathrm{a}, \mathrm{b}}$ Means in a row with the same superscript do not differ significantly $(P>0.05)$.

${ }^{1}$ Mean $( \pm \mathrm{SD})$ of panel scores on a 10 -point scale on duplicate cheese-making trials.

Table 6. Flavor intensity and flavor quality scores ${ }^{1}$ of cheeses made with commercial starter culture (CSC) and $\mathrm{BCV}^{+}$wild strains of Lactococcus lactis.

\begin{tabular}{llllll}
\hline & & & $0.006 \mathrm{U} / L \mathrm{CSC}$ & $0.004 \mathrm{U} / \mathrm{L} \mathrm{CSC}$ & $0.002 \mathrm{U} / \mathrm{L} \mathrm{CSC}$ \\
& $(\mathrm{d})$ & $0.008 \mathrm{U} / \mathrm{L} \mathrm{CSC}$ & $2.5 \mathrm{ml} / \mathrm{LCV}^{+}$ & $5 \mathrm{ml} / \mathrm{L} \mathrm{BCV}$ & $7.5 \mathrm{ml} / \mathrm{L} \mathrm{BCV}$ \\
\hline Flavor intensity & 60 & $6.20 \pm 0.20^{\mathrm{a}}$ & $6.29 \pm 0.51^{\mathrm{a}}$ & $6.79 \pm 0.17^{\mathrm{a}}$ & $6.87 \pm 0.44^{\mathrm{a}}$ \\
& 120 & $6.96 \pm 0.28^{\mathrm{a}}$ & $6.93 \pm 0.17^{\mathrm{a}}$ & $7.39 \pm 0.32^{\mathrm{a}}$ & $7.39 \pm 0.02^{\mathrm{a}}$ \\
Flavor quality & 60 & $6.17 \pm 0.55^{\mathrm{b}}$ & $5.55 \pm 0.14^{\mathrm{ab}}$ & $5.27 \pm 0.29^{\mathrm{a}}$ & $4.77 \pm 0.55^{\mathrm{a}}$ \\
& 120 & $7.03 \pm 0.55^{\mathrm{b}}$ & $6.12 \pm 0.25^{\mathrm{a}}$ & $6.12 \pm 0.16^{\mathrm{a}}$ & $5.60 \pm 0.09^{\mathrm{a}}$ \\
\hline
\end{tabular}

${ }^{\mathrm{a}, \mathrm{b}}$ Means in a row with the same superscript do not differ significantly $(P>0.05)$.

${ }^{1}$ Mean $( \pm \mathrm{SD})$ of panel scores on a 10 -point scale on duplicate cheese-making trials. 
(Molimard and Spinnler, 1996) may contribute to the high positive correlations between flavor intensity and these compounds found in the present work.

Flavor quality, as judged by trained panelists, tended to decrease in both experiments as the inoculation level of $\mathrm{BCV}^{+}$strains increased (Tables 5 and 6). However, those results must be regarded with caution, as the estimate of trained panelists cannot be considered to be representative of the general consumers of ewes' milk cheeses. In cheeses made with different ratios of $\mathrm{BCV}^{-}$and $\mathrm{BCV}^{+}$strains of $L$. lactis a negative correlation $(\mathrm{r}=-0.712)$ was recorded on $\mathrm{d} 120$ between flavor quality and the inoculation level of $\mathrm{BCV}^{+}$strains. In cheeses made with $\mathrm{CSC}$ and $\mathrm{BCV}^{+}$strains, the negative correlation was recorded on day $60(\mathrm{r}=-0.801)$ and day $120(\mathrm{r}=-0.825)$.

Negative correlations between flavor quality and the level of volatile compounds in 120-d-old cheeses were recorded for 2-methylpropanol ( $\mathrm{r}=-0.739)$, 3-methylbutanol $(\mathrm{r}=-0.770)$, isoamyl acetate $(\mathrm{r}=-0.761)$, isobutyl butyrate $(\mathrm{r}=-0.742)$ and isoamyl butyrate $(\mathrm{r}=-0.719)$ in cheeses made with $\mathrm{BCV}^{-}$and $\mathrm{BCV}^{+}$strains. In $120-$ $\mathrm{d}$-old cheeses made with $\mathrm{CSC}$ and $\mathrm{BCV}^{+}$strains, flavor quality correlated negatively with the levels of aldehydes such as 2-methylbutanal $(\mathrm{r}=-0.837)$ and 3 -methylbutanal $(\mathrm{r}=-0.791)$, alcohols such as 2-methylpropa$\operatorname{nol}(\mathrm{r}=-0.840)$, 2-pentanol $(\mathrm{r}=-0.711)$ and 3-methylbutanol $(\mathrm{r}=-0.864)$, and esters such as isobutyl acetate $(\mathrm{r}$ $=-0.762)$, isoamyl acetate $(r=-0.741)$, isobutyl butyrate $(\mathrm{r}=-0.831)$ and isoamyl butyrate $(\mathrm{r}=-0.805)$.

The branched-chain alcohols have a considerably higher perception threshold (about 50-fold in skim milk) and are probably of less significance for flavor than the corresponding aldehydes (Sheldon et al., 1971; Morgan, 1976). Nevertheless, in the present work 3-methylbutanol and 2-methylpropanol were found in concentrations 100 to 500 times those of the corresponding aldehydes, which would explain their effect on flavor-quality scores.

Descriptors used by panelists to define the unusual flavor notes present in cheeses made with the highest levels of $\mathrm{BCV}^{+}$strains were burnt/toasted/unclean, fruity/banana/pineapple and, to a lesser extent, nuts/ sunflower seeds and glue/solvent-like/gum. Some of those terms were used in previous works to describe the flavor of milk cultures or cheeses containing wild lactococcal strains: burnt (Morgan, 1970; Sheldon et al., 1971; Morgan, 1976; Weerkamp et al., 1996), unclean (Dunn and Lindsay, 1985), fruity (Weerkamp et al., 1996; Ayad et al., 1999; Ayad et al., 2000), nuts (Morgan, 1970), or solvent-like (Sheldon et al., 1971).

Methylaldehydes and methylalcohols produced by $S$. lactis var. maltigenes have been generally recognized as off-flavors or flavor defects in milk and cheeses (Mor- gan, 1976; Dunn and Lindsay, 1985; Molimard and Spinnler, 1996). However, such branched-chain volatiles are also recognized as key flavor compounds in some cheese varieties (Bills et al., 1965; Bosset and Gauch, 1993; Barbieri et al., 1994; Engels et al., 1997). Cheese fat may also serve as a solvent for methylaldehydes and methylalcohols and mask the strong flavor due to the presence of high concentrations of these compounds (Braun and Olson, 1986).

Fruity flavors, considered as off-flavors in some cheeses, are due to the presence of esters (Barbieri et al., 1994; Molimard and Spinnler, 1996). Ayad et al. (1999, 2000) also found these fruity notes, attributed to the presence of low amounts of ethylesters, in the flavor of milk cultures and cheeses made with wild lactococcal strains.

Most consumers are not accustomed to intensely flavored raw milk cheeses. Nevertheless, these products may be attractive to connoisseurs of traditional raw milk cheeses, as "there is a cheese for every taste-preference and a taste-preference for every cheese" (Olson, 1990). It has been suggested that certain flavors, when present in balance with other volatile compounds may be applied in a positive way in speciality cheeses, depending on the defined starters used. Therefore, it is feasible to develop tailor-made starter cultures to modify the balance of branched-chain flavor compounds with other volatile compounds, in order to get a moderate and more desirable expression of unusual "novel" flavors. Future work exploring sensory-perceived flavors contributed by $\mathrm{BCV}^{+} L$. lactis strains and actual consumer preferences with regard to novel cheese flavors seems essential for the development of those starter cultures.

\section{CONCLUSIONS}

From the results obtained in the present work, milk inoculation with the two $\mathrm{BCV}^{+} L$. lactis wild strains had a considerable influence on the volatile profile of cheese. An effect on the abundance of some volatile compounds was to be expected, because both $\mathrm{BCV}^{+}$wild strains were known to produce high amounts of 2methyl propanol, 3-methyl butanol, and 3-methyl butanal. However, the abundance of 27 out of 50 volatile compounds was influenced when the two $\mathrm{BCV}^{+}$L. lactis strains were used in combination with two $\mathrm{BCV}^{-} L$. lactis strains, and the abundance of 14 volatile compounds when the two $\mathrm{BCV}^{+}$strains were used in combination with a commercial starter culture.

Changes in the volatile profile of cheeses made using a high level of $\mathrm{BCV}^{+}$L. lactis strains resulted in unusual flavors which tended to affect sensory characteristics. A certain enhancement of flavor intensity of cheeses 
made using a high level of $\mathrm{BCV}^{+} L$. lactis strains was observed. Also, a certain impairment of their flavor quality was reported by trained panelists, which estimate cannot be considered representative of the general consumers' preference.

\section{REFERENCES}

Ayad, E. H. E., A. Verheul, C. de Jong, J. T. M. Wouters, and G. Smit. 1999. Flavour forming abilities and amino acid requirements of Lactococcus lactis isolated from artisanal and non-dairy origin. Int. Dairy J. 9:725-735.

Ayad, E. H. E., A. Verheul, W. J. M. Engels, J. T. M. Wouters, and G. Smit. 2001. Enhanced flavour formation by combination of selected lactococci from industrial and artisanal origin with focus on completion of a metabolic pathway. J. Appl. Microbiol. 90:59-67.

Ayad, E. H. E., A. Verheul, J. T. M. Wouters, and G. Smit. 2000. Application of wild starter cultures for flavour development in pilot plant cheese making. Int. Dairy J. 10:169-179.

Barbieri, G., I. Bolzoni, M. Careri, A. Manglia, G. Parolari, S. Spagonoli, and R. Virgili. 1994. Study of the volatile fraction of Parmesan cheese. J. Agric. Food Chem. 42:1170-1176.

Bérodier, F., P. Lavanchy, M. Zannoni, J. Casals, L. Herrero, and C. Adamo. 1997. A guide to the sensory evaluation of smell, aroma and taste of hard and semi-hard cheeses. Lebensm. Wiss. Technol. 30:653-664.

Bills, D. D., M. E. Morgan, L. M. Libbey, and E. A. Day. 1965. Identification of compounds responsible for fruity flavor defect of experimental Cheddar cheeses. J. Dairy Sci. 48:1168-1173.

Bosset, J. O., and G. Gauch. 1993. Comparison of the volatile flavour compounds of six European "AOC" cheeses using a new dynamic headspace GC-MS method. Int. Dairy J. 3:423-460.

Braun, S. D., and N. F. Olson. 1986. Microencapsulation of cell-free extracts to demonstrate the feasibility of heterogeneous enzyme systems and cofactor recycling for development of flavor in cheese. J. Dairy Sci. 69:1202-1208.

Centeno, J. A., P. Gaya, M. Medina, and M. Nuñez. 2002. Crossinhibition among wild strains of Lactococcus lactis isolated from the same ecological niche. J. Food Prot. 65:205-210.

Cogan, T. M. 1995. Flavour production by dairy starter cultures. J. Appl. Bacteriol. 79:49S-64S.

Cogan, T. M., M. Barbosa, E. Beuvier, B. Bianchi-Salvadori, P. S. Cocconcelli, I. Fernandes, M. J. Gómez, R. Gómez, G. Kalantzopoulos, A. Ledda, M. Medina, M. Rea, and E. Rodríguez. 1997. Characterization of lactic acid bacteria in artisanal dairy products. J. Dairy Res. 64:409-421.

Dunn, H. C., and R. C. Lindsay. 1985. Evaluation of the role of microbial Strecker-derived aroma compounds in unclean-type flavors of Cheddar cheese. J. Dairy Sci. 68:2859-2874.

Engels, W. J. M., R. Dekker, C. De Jong, R. Neeter, and S. Visser. 1997. A comparative study of volatile compounds in the watersoluble fraction of various types of ripened cheese. Int. Dairy J. 6:1-9.

Fox, P. F., and J. M. Wallace. 1997. Formation of flavor compounds. Adv. Appl. Microbiol. 45:17-85.

Garde, S., P. Gaya, M. Medina, and M. Nuñez. 1997. Acceleration of flavour formation in cheese by a bacteriocin-producing adjunct lactic culture. Biotechnol. Lett. 19:1011-1014.

Gaya, P., M. Babín, M. Medina, and M. Nuñez. 1999. Diversity among lactococci isolated from ewes' raw milk and cheese. J. Appl. Microbiol. 87:849-855.
Harper, W. J., A. Carmona de Catril, and J. L. Chen. 1980. Esterases of lactic streptococci and their stability in cheese slurry systems. Milchwissenschaft 35:129-132.

Jackson, H. W., and M. E. Morgan. 1954. Identity and origin of the malty aroma substance from cultures of Streptococcus lactis var. maltigenes. J. Dairy Sci. 37:1316-1324.

Kamaly, K. M., M. El Soda, and E. H. Marth. 1988. Esterolytic activity of Streptococcus lactis, Streptococcus cremoris and their mutants. Milchwissenschaft 43:346-349.

McSweeney, P. L. H., and M. J. Sousa. 2000. Biochemical pathways for the production of flavour compounds in cheeses during ripening: A review. Lait 80:293-324.

Molimard, P., and H. E. Spinnler. 1996. Review: Compounds involved in the flavor of surface mold-ripened cheese: origins and properties. J. Dairy Sci. 79:169-184.

Morales, P., E. Fernández-García, P. Gaya, M. Medina, and M. Nuñez. 2001. Hydrolysis of caseins and formation of hydrophobic and hydrophilic peptides by wild strains of Lactococcus lactis isolated from raw ewes' milk cheese. J. Appl. Microbiol. 91:907-915.

Morgan, M. E. 1970. Microbial flavor defects in dairy products and methods for their simulation. I. Malty flavor. J. Dairy Sci. 53:270-272.

Morgan, M. E. 1976. The chemistry of some microbially induced flavor defects in milk and dairy foods. Biotechnol. Bioeng. 18:953-965.

Morgan, M. E., R. C. Lindsay, L. M. Libbey, and R. L. Pereira. 1966. Identity of additional aroma constituents in milk cultures of Streptococcus lactis var. maltigenes. J. Dairy Sci. 49:15-18.

Nuñez, M., A. M. Guillén, M. A. Rodríguez-Marin, A. M. Marcilla, P. Gaya, and M. Medina. 1991. Accelerated ripening of ewes' milk Manchego cheese: the effect of neutral proteinases. J. Dairy Sci. 74:4108-4118.

Olson, N. F. 1990. The impact of lactic acid bacteria on cheese flavor. FEMS Microbiol. Rev. 87:131-147.

Oumer, A., P. Gaya, E. Fernández-García, R. Mariaca, S. Garde, M. Medina, and M. Nuñez. 2001. Proteolysis and formation of volatile compounds in cheese manufactured with a bacteriocin-producing adjunct culture. J. Dairy Res. 68:117-129.

Preininger, M., R. Warmke, and W. Grosch. 1996. Identification of the character impact flavour compounds of Swiss cheese by sensory studies of models. Z. Lebensm. Unters. Forsch. 202:30-34.

Rijnen, L., A. Delacroix-Buchet, D. Demaizières, J. L. Le Quére, J.C. Gripon, and M. Yvon. 1999. Inactivation of lactococcal aromatic aminotransferase prevents the formation of floral aroma compounds from aromatic amino acids in semi-hard cheese. Int. Dairy J. 9:877-885.

Salama, M. S., W. E. Sandine, and S. J. Giovannoni. 1993. Isolation of Lactococcus lactis subsp. cremoris from nature by colony hybridization with RNA probes. Appl. Environ. Microbiol. 59:3941-3945.

Sheldon, R. M., R. C. Lindsay, L. M. Libbey, and M. E. Morgan. 1971. Chemical nature of malty flavor and aroma produced by Streptococcus lactis var. maltigenes. Appl. Microbiol. 22:263-266.

Stadhouders, J. 1975. Microbes in milk and dairy products. An ecological approach. Neth. Milk Dairy J. 29:104-126.

Steel, R. G. D., and J. H. Torrie. 1980. Principles and Procedures of Statistics, a Biometrical Approach. Singapore: McGraw-Hill International.

Tucker, J. S., and M. E. Morgan. 1967. Decarboxylation of ( $\alpha$-keto acids by Streptococcus lactis var. maltigenes. Appl. Microbiol. 15:694-700.

Urbach, G. 1993. Relations between cheese flavour and chemical composition. Int. Dairy J. 3:389-422.

Urbach, G. 1995. Contribution of lactic acid bacteria to flavour compound formation in dairy products. Int. Dairy J. 5:877-903.

Weerkamp, A. H., N. Klijn, R. Neeter, and G. Smit. 1996. Properties of mesophilic lactic acid bacteria from raw milk and naturally fermented raw milk products. Neth. Milk Dairy J. 50:319-332. 